\title{
Analysis of Phenolic Compounds and Some Important Analytical Properties in Selected Apricot Genotypes
}

\author{
Martina Göttingerová \\ Department of Fruit Science, MENDEL University in Brno, Valtická 337, \\ 69144 Lednice, Czech Republic
}

\author{
Michal Kumšta \\ Department of Viticulture and Enology, Faculty of Horticulture in \\ Lednice, MENDEL University in Brno, Valtická 337, 69144 Lednice, \\ Czech Republic
}

\section{Eliška Rampáčková, Tomáš Kiss, and Tomáš Nečas \\ Department of Fruit Science, MENDEL University in Brno, Valtická 337, 69144 Lednice, Czech Republic}

Additional index words. antioxidant capacity, carotenoids, flavonoids, nutrition, phenolic content, Prunus armeniaca, titratable acidity, vitamin C

\begin{abstract}
The apricot is attractive for several reasons, with the most important being the harvest period and the significant amount of contained substances that positively affect human health. This report discusses the identification and quantification of phenolic substances in 15 selected apricots. The following 14 phenolic compounds were identified: 4aminobenzoic acid, chlorogenic acid, cinnamic acid, flavonols quercetin and quercitrin, isoquercetin (quercetin-3- $\beta$-D-glucoside), rutin, resveratrol, vanillin, phloridzin, phloretin, epicatechin, catechin, and transpiceid. Significant amounts of phytochemicals found in apricot fruits are chlorogenic acid $[0.69-21.94 \mathrm{mg} / 100 \mathrm{~g}$ fresh weight $(\mathrm{FW})]$, catechin $(0.55-10.75 \mathrm{mg} / 100 \mathrm{~g}$ FW), epicatechin $(0.04-13.52 \mathrm{mg} /$ $100 \mathrm{~g}$ FW), and rutin (1.49-20.44 mg/100 g FW). Rutin and chlorogenic acid were the dominant compounds found in the studied set of cultivars. Furthermore, other important analytical properties of fruits (total acids, vitamin $C$, total content of phenolic substances, flavonoids, antioxidant capacity, and carotenoids) were also determined.
\end{abstract}

Apricot (Prunus armeniaca L.) is, after apple and pear, one of the most widespread fruit species in the temperate zone. It is undoubtedly one of the most attractive stone fruit species grown in the Czech Republic. This is largely because of the taste and aroma of the fruits, as well as the attractiveness of its appearance and harvest season.

From a nutritional point of view, the apricot is an interesting supplement to the human diet because it contains several beneficial substances. The fruit pulp contains up to $90 \%$ water and is also a good source of fiber. The predominant sugar in apricot is sucrose. Glucose, fructose, maltose, and raffinose are also present, but

Received for publication 16 July 2021. Accepted for publication 2 Sept. 2021

Published online 21 October 2021.

This research was funded by project IGA-ZF/2020DP010, The determination of the content of phenolic substances in selected genotypes of apricots. The results of this research were also obtained with the support of a Ministry of Agriculture project NAZV/QK1910137. Laboratory equipment was acquired under project CZ.02.1.01/0.0/0.0/16_017/ 0002334 research infrastructure for young scientists. T.N. is the corresponding author. E-mail tomas. necas@mendelu.cz.

This is an open access article distributed under the CC BY-NC-ND license (https://creativecommons. org/licenses/by-nc-nd/4.0/). in lower concentrations (Gatti et al., 2009). The most important organic acids in apricot are malic acid (500-900 mg/100 g), citric acid (30-50 mg/100 g), and tartaric acid (Chen et al., 2009; Fatima et al., 2018). Vitamins A, $\mathrm{C}$, and $\mathrm{E}$ and provitamin $\mathrm{A}$ are present in these fruits (Ali et al., 2011, 2015). Minerals and trace elements are represented mainly by potassium, phosphorus, calcium, magnesium, and, to a lesser extent, iron, sodium, zinc, copper, manganese, boron, cobalt, selenium, and others (Leccese et al., 2008).

An important component is a large number of bioactive substances that together provide high antioxidant capacity (Fratianni et al., 2018). Phenolic compounds in apricot are represented primarily by gallic acid, chlorogenic acid, neochlorogenic acid, caffeic acid, pcoumaric acid, ferulic acid, catechin, epicatechin, quercetin-3galactoside, quercetin-3rutinoside, and kaempferol-3-rutinoside (Dragovic-Uzelac et al., 2005). Chlorogenic acid, catechin, epicatechin, and rutin are the most common phytochemicals found in apricot fruits (Carbone et al., 2018; Dragovic-Uzelac et al., 2005, 2007).

Research has been focused on apricot kernels, which contain proteins, fiber, phenolic compounds, vitamins, and minerals. However, they also contain the toxic cyanogenic glycoside amygdalin, the content of which varies depending on the taste of the kernel. Bitter kernels contain up to 10-times more amygdalin than sweet apricot kernels (Rampáčková et al., 2021). According to Turan et al. (2007), the total oil content of apricot kernel ranges from $40.23 \%$ to $53.19 \%$, and it is predominantly formed by oleic acid $(70.83 \%)$. Göttingerová et al. (2020) studied the constituents of apricot blossoms, which are an interesting supplement to the human diet. The study provided information about a nutrient content comparable to that found in common fruits such as plums, blueberries, and blackcurrants. Total phenols in the flowers in their study ranged from 404.08 to $768.45 \mathrm{mg}$ gallic acid equivalent (GAE)/100 g FW.

Natural phenolic compounds have attracted the interest of many researchers because of the possible relationship between their dietary content and the lower incidence rates of cancer and cardiovascular diseases (La Vecchia et al., 2001; Long et al., 2001). Their antimutagenic, anticarcinogenic, and anti-inflammatory effects have also been confirmed, but large clinical studies to support these effects in humans are still lacking. Antioxidant activity is closely related to the content of phenolic compounds. Some phenolic compounds have been shown to have a higher antioxidant activity compared with others (Ou et al., 2002). This fact is important when the fruit ripens because the content of individual phenolic compounds significantly varies during the ripening. Immature fruit show the highest level of polyphenols, and these levels decrease with gradual ripening (Dragovic-Uzelac et al., 2007). The percentage of individual substances may also differ according to cultivars, vegetation conditions, and applied agricultural techniques, as well as according to the age or development of the fruit, and even based on the individual part of the fruit (skin, flesh, etc.).

Because of the contents of the aforementioned substances, this fruit is widely used in popular medicine. Apricots have a significant overall positive effect on the human body. They enhance the growth of nails, hair, and skin by acting against free radicals, have an overall rejuvenating effect, slow the aging process, help with asthma and fatigue, breakdown fats, have an antistress effect, help treat anemia, nervous system diseases, and insomnia, improve eyesight, reduce body fat, and act against constipation (Dulf et al., 2017; Enomoto et al., 2010).

This study aimed to determine phenolic compounds, organic acids, vitamin C, flavonoids, antioxidant capacity, and carotenoids in the fruits of selected apricot cultivars to highlight that the apricot fruit is a highly nutritious food, rich in functional components.

\section{Materials and Methods}

Site of planting and plant material. The fruits were harvested from trees grown in the orchard of the Department of Fruit Growing at the Faculty of Horticulture in Lednice located in the South Moravian Region at an 
altitude of $176 \mathrm{~m}$ above sea level with an average annual temperature of $9.7^{\circ} \mathrm{C}$. The whole orchard was supported by drip irrigation. The training system was a free-growing dwarf tree without a terminal on the apricot seedlings rootstock. Five trees were always planted from each cultivar.

Samples were collected at harvest maturity. From each tree of a cultivar, two fruits were taken from the same part of a crown. One sample consisted of 2 fruits taken from each of the 5 trees, in total 10 fruits. For analysis, 15 apricot cultivars (Adriana, Bora, JinNa-Li, Leskora, Lydia, Ninja, Orange Rubis, Pozdní chrámová, Rubista, Sefora, Skarb, Spring Blush, Tsunami, Velkopavlovická, and Veselka) from the Czech and world assortment were selected. Chemical analyses of fresh matter were performed no more than $3 \mathrm{~d}$ after the harvest.

Determination of titratable acidity. The determination of titratable acidity was performed by potentiometric titration with a solution of $0.1 \mathrm{~mol} \cdot \mathrm{L}^{-1} \mathrm{NaOH}$ of a known factor up to $\mathrm{pH} 8.1$ using a combined SenTix $^{\mathrm{TM}} 81 \mathrm{pH}$ electrode (WTW, Prague, Czech Republic) attached to an inoLab $7110 \mathrm{pH}$ meter (WTW) and was expressed as a percentage of malic acid equivalent (Goliáš and Němcová, 2009). The sample used for titration was composed of mixed fruits.

Preparation of the plant samples for analyzing the total phenolic content, total flavonoids, total antioxidant capacity, and phenolic substances. The contents of secondary metabolites (phenolic compounds, flavonoids, and antioxidant capacity) were determined from a methanol extract of fresh fruit material. Five grams of the sample were homogenized with a hand blender in $25 \mathrm{~mL}$ of $75 \%$ methanol. The extract was left to stand for $24 \mathrm{~h}$; then, it was filtered through filter paper into a $50-\mathrm{mL}$ measuring flask and filled to the line with $75 \%$ methanol. Samples were placed in a 20 $\mathrm{mL}$ plastic bottle and kept at $-20^{\circ} \mathrm{C}$ until the analysis (Zbíral, 2005).

Determination of individual phenolic substances. The concentration of individual phenolic substances was determined by the highperformance liquid chromatography (HPLC) method. The methanol extract was centrifuged to remove any residual solids before the analysis, and the clear supernatant was further diluted five times with $100 \mathrm{mM}$ perchloric acid. The diluted extract was analyzed in a LC-10A HPLC system (Shimadzu, Tokyo, Japan). The samples were run in an analytical column (Alltima HP C18, $3 \mu \mathrm{m}$, $3.150 \mathrm{~mm}$; Avantor, Randor, PA), where 15 $\mathrm{mM}$ perchloric acid solution was used as the mobile phase. Detection was performed at wavelengths from 190 to $650 \mathrm{~nm}$. Hydroxycinnamic acid derivatives that had a spectrum analogous to chlorogenic acid were calibrated to chlorogenic acid, and glycoside quercetin was calibrated to rutin.

Determination of the individual components was based on the calibration curves of the following standards:
$192 \mathrm{~nm}$ : 4-aminobenzoic acid

$200 \mathrm{~nm}$ : catechin, epicatechin

$275 \mathrm{~nm}$ : vanillin, cinnamid acid

$285 \mathrm{~nm}$ : phloridzin, phloretin

$310 \mathrm{~nm}$ : transpiceid, transresveratrol

$325 \mathrm{~nm}$ : chlorogenic acid

$350 \mathrm{~nm}$ : rutin, quercetin-3- $\beta-D-G l u k o s i d$, quercitrin

\section{$370 \mathrm{~nm}$ : quercetin}

Determination of L-ascorbic acid. The concentration of L-ascorbic acid (vitamin C) was determined with HPLC according to the method of Sawant et al. (2010). For analysis, $20 \mathrm{~g}$ of fruit material was homogenized with a hand blender in $25 \mathrm{~mL}$ of a $0.1-\mathrm{mol} \cdot \mathrm{L}^{-1}$ solution of oxalic acid. Then, the sample was filtered through gauze into a $100-\mathrm{mL}$ measuring flask, and oxalic acid was added to the line. Twenty milliliters of this solution was centrifuged in EBA 12 (Hettich, Vlotho, Germany) for $10 \mathrm{~min}$ at $3500 \mathrm{rpm}$. The supernatant was filtered through a $0.45-\mu \mathrm{m}$ microfilter before injection into the $\mathrm{ECB}$ 2000 chromatograph (Ecom, České Meziř́ičí, Czech Republic). Samples were run in an analytical column (Pack ODS-AQ S-5 mm, $12 \mathrm{~nm}, 150 \cdot 4.6 \mathrm{~mm}$; YMC, Shimogyoku, Japan); as a mobile phase, tetrabutylammonium hydroxide with oxalic acid and water at a ratio of 10:20:70 was used. The detection was performed at $254 \mathrm{~nm}$, and the qualitative assessment was performed based on the retention data. The quantitative assessment was determined according to the sample and the standard peak area. Vitamin C content was expressed in milligrams per $100 \mathrm{~g} \mathrm{FW}$.

Determination of total phenolic content, total flavonoids, and total antioxidant capacity. Analyses of all parameters were performed according to the methods of Zloch et al. (2004) by using a Specord 50 Plus spectrophotometer (Analytik, Jena, Germany). Total phenolic content was determined after the reaction of sample methanol extracts with the Folin-Ciocalteu reagent at a wavelength of $765 \mathrm{~nm}$. Total phenolic content was expressed in milligrams GAE per $100 \mathrm{~g} \mathrm{FW}$. Total flavonoid content was determined by using aluminum chloride and sodium nitrite. The results were expressed in milligrams catechin equivalent (CAE) per $100 \mathrm{~g} \mathrm{FW}$. The 2.2-diphenyl-1-picrylhydrazyl (DPPH) method was used to determine the total antioxidant capacity. This method is based on the decolorizing property of the hydrogen radical of DPPH with hydrogen donors, including phenolic compounds. Trolox (6hydroxy-2.5.7.8-tetramethylchroman-2-carboxylic acid) was used as a standard, and the total antioxidant capacity was measured at $515 \mathrm{~nm}$ and then expressed in milligrams Trolox equivalent (TE) per $100 \mathrm{~g}$ FW.

Determination of total carotenoids. Before the determination of the carotenoid content, the fruits were sliced into thin sections and dried in a heat chamber (FED 400; Binder, Tuttlingen, Germany) at $50{ }^{\circ} \mathrm{C}$ for $24 \mathrm{~h}$ and pulverized in a mill (Pulverisette 11; Fritsch, Weimar, Germany). Next, the pigments were extracted from the samples with acetone. Spectrophotometric determination of photosynthetically active pigments (carotenoids) was performed using a Specord 50 Plus spectrophotometer at $440 \mathrm{~nm}$ according to Holm (1954). The concentration of carotenoids is expressed in milligrams per $100 \mathrm{~g} \mathrm{FW}$.

Statistical analysis. The established data were processed using Microsoft Excel (Redmond, WA) and Statistica 12 software (TIBCO Software Inc., Palo Alto, CA). A single-factor analysis of variance (level of significance, $P \leq$ 0.05 ) was used for statistical processing, and Tukey's test was subsequently used to assess the statistical significance of differences between individual apricot cultivars. A correlation matrix between the total phenolic content and antioxidant capacity was established as well.

\section{Results}

One of the main phenolic components in the fruit of the Prunus genus is chlorogenic acid. The content of this acid in the studied group ranged from 0.69 to $21.94 \mathrm{mg} / 100 \mathrm{~g}$ FW. Significantly high values were measured in the cultivars Ninja $(21.94 \mathrm{mg} / 100 \mathrm{~g} \mathrm{FW})$, Adriana (15.31 mg/100 g FW), Spring Blush (12.06 mg/100 g FW), and Velkopavlovická $(11.69 \mathrm{mg} / 100 \mathrm{~g} \mathrm{FW})$. However, low values were recorded in the cultivars Orange Rubis, Jin-Na-Li, Sefora, and Skarb (0.69, 0.793, 0.85 , and $0.90 \mathrm{mg} / 100 \mathrm{~g} \mathrm{FW}$, respectively).

Catechin and epicatechin are the most common substances from the group of flavanols (flavan-3-ol) that can be found in many plant species. Of these compounds, catechin was the most abundant, with values ranging from 0.55 to $10.75 \mathrm{mg} / 100 \mathrm{~g} \mathrm{FW}$. The highest amount of catechin was in "Spring Blush" $(10.75 \mathrm{mg} / 100 \mathrm{~g} \mathrm{FW})$, whereas the lowest amounts were measured in 'Skarb' $(0.55 \mathrm{mg})$ $100 \mathrm{~g} \mathrm{FW})$ and 'Jin-Na-Li' $(0.85 \mathrm{mg} / 100 \mathrm{~g}$ $\mathrm{FW}$ ). The content of epicatechin ranged from 0.04 to $13.52 \mathrm{mg} / 100 \mathrm{~g} \mathrm{FW}$. Czech cultivars and one Slovak cultivar had the highest contents of epicatechin among analyzed cultivars. The highest values were measured in the Velkopavlovická (13.52 mg/100 g FW) and Lydia cultivars $(11.73 \mathrm{mg} / 100 \mathrm{~g} \mathrm{FW})$, followed by Adriana, Veselka, and Pozdní chrámová $(8.79,5.59$, and $4.35 \mathrm{mg} / 100 \mathrm{~g}$ $\mathrm{FW}$, respectively). However, the lowest value was measured in 'Jin-Na-Li' $(0.04 \mathrm{mg} / 100 \mathrm{~g}$ FW).

The most abundant compound with the flavonoid scaffold was quercitrin (0.02-3.61 $\mathrm{mg} / 100 \mathrm{~g} \mathrm{FW}$ ). The highest values were measured in 'Jin-Na-Li' (3.61 mg/100 g FW), 'Spring Blush' (3.08 mg/100 g FW), and 'Tsunami' (2.31 mg/100 g FW). On the contrary, in 'Lydia' $(0.02 \mathrm{mg} / 100 \mathrm{~g} \mathrm{FW})$ and 'Skarb' $(0.07 \mathrm{mg} / 100 \mathrm{~g} \mathrm{FW})$, the content of this compound was minimal. The average content of quercetin was $0.045 \mathrm{mg} / 100 \mathrm{~g}$ FW. Significant values were measured in 'Bora' and 'Jin-Na-Li', which contained 0.232 and $0.111 \mathrm{mg} / 100 \mathrm{~g} \mathrm{FW}$, respectively. The content of quercetin was not detected in the cultivar Adriana, and a very low content was detected in Sefora $(0.0061 \mathrm{mg} / 100 \mathrm{~g}$ 
FW). The content of another bioflavonoid, rutin, ranged from 1.50 to $20.44 \mathrm{mg} / 100 \mathrm{~g}$ FW. A significantly high content of rutin was measured in 'Spring Blush' (20.44 mg/100 g FW), 'Velkopavlovická' (18.42 mg/100 g FW), and 'Ninja' (15.97 mg/100 g FW). The lowest contents were measured in 'Skarb' and 'Lydia' (1.50 and $1.58 \mathrm{mg} / 100 \mathrm{~g} \mathrm{FW}$, respectively).

The remaining phenolic compounds with corresponding measured values are listed in Tables 2 and 3. Differences between the cultivars in all individual determinations were evaluated as highly significant (Tables 1-3).

In the examined group of cultivars, the total content of phenolic substances ranged from 57.33 to $571.93 \mathrm{mg}$ GAE/100 g FW. The highest proportions of total phenolic substances were in 'Velkopavlovická' (571.93 mg GAE/100 g FW), followed by 'Lydia' (292.64 mg GAE/100 g FW), 'Spring Blush' (286.27 mg GAE/100 g FW), and 'Adriana' (274.32 mg GAE/100 g FW). However, the lowest values of phenolic substances were measured in 'Skarb' (57.33 mg GAE/100 g FW), 'Sefora' (66.58 mg GAE/100 g FW), and 'Orange Rubis' (74.69 mg GAE/100 g FW). The differences between the cultivars were highly significant (Table 4).

The highest proportions of flavonoids were measured in the cultivars Velkopavlovická (99.78 mg CAE/100 g FW) and Spring Blush (48.82 mg CAE/100 g FW). The lowest values were recorded in the cultivars Pozdní chrámová, Jin-Na-Li, Skarb, and Sefora (2.49, 6.06, 6.48, and $8.78 \mathrm{mg} \mathrm{CAE} / 100 \mathrm{~g} \mathrm{FW}$, respectively). The average value of flavonoids in the tested group reached $25.95 \mathrm{mg} \mathrm{CAE} / 100$ $\mathrm{g}$ FW. The differences between the cultivars were highly significant (Table 4).

Using the DPPH (2,2-diphenyl-1-picrylhydrazyl) method, the average value of antioxidant activity in apricot fruits was 203.42 $\mathrm{mg}$ TE/100 g FW. The highest values were measured in 'Velkopavlovická' (249.08 mg TE/100 g FW), 'Leskora' (243.44 mg TE/ $100 \mathrm{~g} \mathrm{FW}$ ), and 'Lydia' (241.93 mg TE/100 g FW). 'Veselka' (240.24 mg TE/100 g FW) also showed a high value of antioxidant capacity. The lowest total antioxidant capacity was measured in 'Adriana' (161.47 mg TE/100 g FW) and 'Jin-Na-Li' (163.98 mg $\mathrm{TE} / 100 \mathrm{~g}$ FW). The differences between the cultivars were highly significant (Table 4).

The average content of carotenoids in the studied cultivars was $0.79 \mathrm{mg} / 100 \mathrm{~g} \mathrm{FW}$. The cultivars with the highest content of carotenoids were Bora $(1.40 \mathrm{mg} / 100 \mathrm{~g} \mathrm{FW})$, Lydia $(1.30 \mathrm{mg} / 100 \mathrm{~g} \mathrm{FW})$, and Jin-Na-Li (1.11 $\mathrm{mg} / 100 \mathrm{~g} \mathrm{FW}$ ). The lowest values were found in Pozdní chrámová, Skarb, and Spring Blush cultivars $(0.44,0.45$, and $0.46 \mathrm{mg} / 100 \mathrm{~g} \mathrm{FW}$, respectively). The differences between the cultivars were highly significant (Table 4).

The average content of ascorbic acid (vitamin C) in the studied cultivars was 6.49 $\mathrm{mg} / 100 \mathrm{~g} \mathrm{FW}$. The cultivars with the highest vitamin C content were Bora $(13.15 \mathrm{mg} / 100$ g FW), Jin-Na-Li (10.78 mg/100 g FW), and Skarb (10.28 mg/100 g FW). The lowest values from the evaluated set of cultivars were measured in Tsunami $(1.86 \mathrm{mg} / 100 \mathrm{~g} \mathrm{FW})$ and Spring Blush (2.83 mg/100 g FW). The differences between the cultivars were highly significant (Table 4).

The highest acid contents were found in the cultivars Bora (3.01\% malic acid), Lydia (2.66\% malic acid), and Ninja (2.47\% malic acid). The cultivars with the lowest acid content were Rubista $(0.72 \%$ malic acid), JinNa-Li (0.77\% malic acid), and Skarb (0.79\% malic acid). The average acid content in the analyzed cultivars was $1.63 \%$ malic acid. The differences between the cultivars were highly significant (Table 4).

\section{Discussion}

Fruits present complex mixtures of polyphenols. The phenolic substances in fruits are mainly phenolic acids and flavonoids. Apricot is considered a good source of these compounds and has been studied worldwide. Kalyoncu et al. (2009) demonstrated high concentrations of phenolic substances in immature fruits. Their concentration usually decreases with fruit ripeness; however, the content of some phenolic compounds is stable or increases with ripeness. Among the most stable polyphenols are flavan-3-ols, chlorogenic acid, and quercetin-3-rutinoside, which are dominant during all ripening stages of all apricot cultivars (Dragovic-Uzelac et al., 2007). On the contrary, the contents of carotenoids (especially $\beta$-carotene, zeaxantin, lutein, neoxantine) and anthocyanide dyes (pigments) increase with ripeness by up to $70 \%$ to $85 \%$ (Dragovic-Uzelac et al., 2007; Römer et al., 2000). This is largely because of the coloring of the fruit (finish of the blush). According to Sass-Kiss et al. (2005), chlorogenic, caffeic, $\beta$-coumaric, p-coumaric, and ferulic acids are the most common phenolic acids found in apricots. Chlorogenic acid, catechin, epicatechin, and rutin are the most common phytochemicals found in apricot cultivars (Carbone et al., 2018). Dragovic-Uzelac et al. $(2005,2007)$ considered chlorogenic acid (3-O-caffeoylquinic acid, also called CGA) as the dominant phenolic compound in Croatian cultivars. Akbulut and Artik (2002) reported catechins as the most common phenolic compound in Turkish apricot cultivars. Our results show that catechin was the most abundant phenolic compound in all analyzed apricot cultivars (Fig. 1, Table 1). An article by Fan et al. (2018) agrees with this statement.

In the examined group of cultivars, the total content of phenolic substances ranged from 57.33 to $571.93 \mathrm{mg} \mathrm{GAE} / 100 \mathrm{~g} \mathrm{FW}$. Previously, Rapisarda et al. (1999) monitored the content of total phenols in selected apricot cultivars in which the measured values ranged from 58.4 to $309.5 \mathrm{mg}$ GAE/100 g FW. Drogoudi et al. (2008) reported values of 30.3 to $742.2 \mathrm{mg} \mathrm{GAE} / 100 \mathrm{~g} \mathrm{FW}$, depending on the cultivar. Akbulut and Artik (2002) and Scalzo et al. (2005) reported 769 to 1283 $\mathrm{mg} \mathrm{GAE} / \mathrm{kg}$ of fresh matter and 214 to 266 GAE $\mathrm{mg} / \mathrm{L}$ in different apricot cultivars. Compared with the previous values that refer to total phenolic substances, it is evident that all apricots cultivars included in this study have significant amounts of phenolic compounds.

The content of total flavonoids in the tested set of cultivars ranged from 2.49 to

Table 1. Phenolic compounds chlorogenic acid, rutin, catechin, epicatechin, quercitrin, and quercetin in fruits of apricot cultivars.

\begin{tabular}{|c|c|c|c|c|c|c|}
\hline Cultivar & $\begin{array}{l}\text { Chlorogenic acid } \\
(\mathrm{mg} / 100 \mathrm{~g})\end{array}$ & $\begin{array}{c}\text { Rutin } \\
(\mathrm{mg} / 100 \mathrm{~g})\end{array}$ & $\begin{array}{l}\text { Catechin } \\
(\mathrm{mg} / 100 \mathrm{~g})\end{array}$ & $\begin{array}{l}\text { Epicatechin } \\
(\mathrm{mg} / 100 \mathrm{~g})\end{array}$ & $\begin{array}{l}\text { Quercitrin } \\
(\mathrm{mg} / 100 \mathrm{~g})\end{array}$ & $\begin{array}{l}\text { Quercetin } \\
(\mathrm{mg} / 100 \mathrm{~g})\end{array}$ \\
\hline$\overline{\text { Adriana }}$ & $15.3 \pm 0.6 \mathrm{f}$ & $11.7 \pm 0.5 \mathrm{f}$ & $4.2 \pm 0.2 \mathrm{~g}$ & $8.8 \pm 0.3 \mathrm{~g}$ & $1.38 \pm 0.05 \mathrm{def}$ & $-z$ \\
\hline Bora & $5.8 \pm 0.1 \mathrm{~d}$ & $5.91 \pm 0.04 \mathrm{c}$ & $3.13 \pm 0.02 \mathrm{f}$ & $1.29 \pm 0.02 \mathrm{c}$ & $0.6 \pm 0.5 \mathrm{bc}$ & $0.23 \pm 0.05 \mathrm{f}$ \\
\hline Leskora & $1.30 \pm 0.08 \mathrm{a}$ & $8.2 \pm 0.5 \mathrm{e}$ & $7.0 \pm 0.3 \mathrm{~h}$ & $1.9 \pm 0.1 \mathrm{~d}$ & $0.99 \pm 0.07 \mathrm{~cd}$ & $0.10 \pm 0.01 \mathrm{de}$ \\
\hline Lydia & $5.7 \pm 0.1 \mathrm{~d}$ & $1.58 \pm 0.08 \mathrm{a}$ & $4.16 \pm 0.06 \mathrm{~g}$ & $11.7 \pm 0.2 \mathrm{~h}$ & $0.023 \pm 0.008 \mathrm{a}$ & $0.0144 \pm 0.0008 \mathrm{abc}$ \\
\hline Ninja & $21.9 \pm 0.7 \mathrm{~g}$ & $16.0 \pm 0.7 \mathrm{~g}$ & $2.14 \pm 0.02 \mathrm{~d}$ & $0.76 \pm 0.03 \mathrm{~b}$ & $2.2 \pm 0.2 \mathrm{gh}$ & $0.05 \pm 0.01 \mathrm{bc}$ \\
\hline Orange Rubis & $0.69 \pm 0.02 \mathrm{a}$ & $6.79 \pm 0.09 \mathrm{~cd}$ & $1.65 \pm 0.03 \mathrm{c}$ & $0.685 \pm 0.005 b$ & $1.82 \pm 0.05 \mathrm{fgh}$ & $0.009 \pm 0.004 \mathrm{ab}$ \\
\hline Sefora & $0.85 \pm 0.05 a$ & $8.4 \pm 0.1 \mathrm{e}$ & $1.15 \pm 0.05 \mathrm{~b}$ & $0.18 \pm 0.01 \mathrm{a}$ & $1.8 \pm 0.2 \mathrm{fg}$ & $0.006 \pm 0.002 \mathrm{ab}$ \\
\hline Skarb & $0.90 \pm 0.06 \mathrm{a}$ & $1.49 \pm 0.02 \mathrm{a}$ & $0.55 \pm 0.03 \mathrm{a}$ & $0.115 \pm 0.003 \mathrm{a}$ & $0.08 \pm 0.03 \mathrm{a}$ & $0.008 \pm 0.004 \mathrm{ab}$ \\
\hline Spring Blush & $12.06 \pm 0.09 \mathrm{e}$ & $20.4 \pm 0.4 \mathrm{i}$ & $10.7 \pm 0.2 \mathrm{j}$ & $2.01 \pm 0.06 \mathrm{~d}$ & $3.1 \pm 0.1 \mathrm{i}$ & $0.037 \pm 0.008 \mathrm{abc}$ \\
\hline Tsunami & $4.0 \pm 0.3 \mathrm{c}$ & $11.2 \pm 0.5 \mathrm{f}$ & $2.5 \pm 0.1 \mathrm{de}$ & $0.85 \pm 0.05 \mathrm{bc}$ & $2.3 \pm 0.2 \mathrm{~h}$ & $0.011 \pm 0.005 \mathrm{ab}$ \\
\hline Veselka & $3.7 \pm 0.4 \mathrm{bc}$ & $4.0 \pm 0.3 \mathrm{~b}$ & $4.1 \pm 0.1 \mathrm{~g}$ & $5.6 \pm 0.2 \mathrm{f}$ & $0.27 \pm 0.06 \mathrm{ab}$ & $0.009 \pm 0.007 \mathrm{ab}$ \\
\hline Velkopavlovická & $11.7 \pm 0.3 \mathrm{e}$ & $18.4 \pm 0.6 \mathrm{~h}$ & $9.0 \pm 0.3 \mathrm{i}$ & $13.5 \pm 0.3 \mathrm{i}$ & $1.61 \pm 0.05 \mathrm{ef}$ & $0.057 \pm 0.008 \mathrm{~cd}$ \\
\hline
\end{tabular}

${ }^{\mathrm{z}}$ Not measured.

The data are displayed as the mean $\pm \mathrm{SD}$ of three replications. Letters a-j refer to the grouping based on Tukey's honestly significant difference test. 
Table 2. Phenolic compounds 4-aminobenzoic acid, transpiceid, quercetin-3- $\beta$-d-glukosid, and phloridzin in fruits of apricot cultivars.

\begin{tabular}{|c|c|c|c|c|}
\hline Cultivar & 4-Aminobenzoic acid (mg/100 g) & Transpiceid $(\mathrm{mg} / 100 \mathrm{~g})$ & Quercetin-3- $\beta$-D-glukosid (mg/100 g) & Phloridzin $(\mathrm{mg} / 100 \mathrm{~g})$ \\
\hline$\overline{\text { Adriana }}$ & $-^{z}$ & $0.04 \pm 0.01 \mathrm{~cd}$ & $2.8 \pm 0.1 \mathrm{i}$ & - \\
\hline Jin-Na-Li & $0.107 \pm 0.001 \mathrm{bcde}$ & $0.0285 \pm 0.0006 b c$ & $3.9 \pm 0.3 \mathrm{j}$ & $0.08 \pm 0.02 \mathrm{~d}$ \\
\hline Leskora & $0.15 \pm 0.01 \mathrm{f}$ & $0.010 \pm 0.005 \mathrm{a}$ & $0.44 \pm 0.05 \mathrm{bcd}$ & $0.035 \pm 0.004 \mathrm{~b}$ \\
\hline Ninja & $0.10 \pm 0.02 \mathrm{bcde}$ & $0.044 \pm 0.005 \mathrm{de}$ & $1.18 \pm 0.07 \mathrm{f}$ & $0.065 \pm 0.002 \mathrm{~cd}$ \\
\hline Orange Rubis & $0.09 \pm 0.01$ bcde & $0.058 \pm 0.003 \mathrm{e}$ & $0.7012 \pm 0.0009 \mathrm{de}$ & $0.037 \pm 0.001 \mathrm{bc}$ \\
\hline Pozdní chrámová & $0.11 \pm 0.03 \mathrm{cdef}$ & $0.028 \pm 0.003 \mathrm{bc}$ & $1.23 \pm 0.07 \mathrm{f}$ & $0.0123 \pm 0.0007 \mathrm{ab}$ \\
\hline Skarb & $0.080 \pm 0.007 \mathrm{bcd}$ & $0.092 \pm 0.005 \mathrm{f}$ & $0.178 \pm 0.006 \mathrm{ab}$ & $0.025 \pm 0.002 \mathrm{ab}$ \\
\hline Spring Blush & $0.12 \pm 0.01 \mathrm{def}$ & $0.010 \pm 0.001 \mathrm{a}$ & $1.77 \pm 0.03 \mathrm{~g}$ & $0.038 \pm 0.008 \mathrm{bc}$ \\
\hline Tsunami & $0.07 \pm 0.02 \mathrm{bc}$ & $0.009 \pm 0.002 \mathrm{a}$ & $1.01 \pm 0.10 \mathrm{ef}$ & - \\
\hline Veselka & $0.088 \pm 0.009 \mathrm{bcde}$ & $0.014 \pm 0.003 \mathrm{ab}$ & $0.32 \pm 0.05 \mathrm{abc}$ & $0.078 \pm 0.008 \mathrm{~d}$ \\
\hline Velkopavlovická & $0.08 \pm 0.02 \mathrm{bcd}$ & $0.04 \pm 0.01 \mathrm{~cd}$ & $2.2 \pm 0.2 \mathrm{~h}$ & $0.14 \pm 0.02 \mathrm{e}$ \\
\hline
\end{tabular}

${ }^{\mathrm{z}}$ Not measured.

The data are displayed as the mean \pm SD of three replications. Letters a-j refer to the grouping based on Tukey's honestly significant difference test.

Table 3. Phenolic compounds transresveratrol, phloretin, vanillin and cinnamid acid in fruits of apricot cultivars.

\begin{tabular}{lcccc}
\hline Cultivar & Transresveratrol $(\mathrm{mg} / 100 \mathrm{~g})$ & Phloretin $(\mathrm{mg} / 100 \mathrm{~g})$ & Vanilin $(\mathrm{mg} / 100 \mathrm{~g})$ & Cinnamid acid $(\mathrm{mg} / 100 \mathrm{~g})$ \\
\hline Adriana & $0.034 \pm 0.003 \mathrm{e}$ & $0.017 \pm 0.006 \mathrm{~cd}$ & $0.029 \pm 0.003 \mathrm{ab}$ & $0.057 \pm 0.003 \mathrm{de}$ \\
Bora & $0.010 \pm 0.004 \mathrm{ab}$ & $0.037 \pm 0.007 \mathrm{e}$ & $0.018 \pm 0.005 \mathrm{a}$ & $0.04 \pm 0.03 \mathrm{bcd}$ \\
Jin-Na-Li & $0.022 \pm 0.003 \mathrm{~cd}$ & $0.014 \pm 0.005 \mathrm{~cd}$ & $0.22 \pm 0.02 \mathrm{~d}$ & $0.014 \pm 0.002 \mathrm{ab}$ \\
Leskora & $0.0104 \pm 0.0007 \mathrm{ab}$ & $0.013 \pm 0.003 \mathrm{bcd}$ & $0.023 \pm 0.002 \mathrm{ab}$ & $0.034 \pm 0.003 \mathrm{abcd}$ \\
Lydia & $0.0052 \pm 0.0005 \mathrm{a}$ & - & $0.025 \pm 0.006 \mathrm{ab}$ & $0.009 \pm 0.002 \mathrm{a}$ \\
Ninja & $0.022 \pm 0.002 \mathrm{~cd}$ & - & $0.019 \pm 0.002 \mathrm{a}$ & $0.020 \pm 0.001 \mathrm{abc}$ \\
Orange Rubis & $0.0104 \pm 0.0002 \mathrm{ab}$ & - & $0.017 \pm 0.004 \mathrm{a}$ & $0.073 \pm 0.002 \mathrm{e}$ \\
Pozdní chrámová & $0.0250 \pm 0.0008 \mathrm{~d}$ & - & $0.02 \pm 0.02 \mathrm{ab}$ & $0.034 \pm 0.003 \mathrm{abcd}$ \\
Rubista & $0.013 \pm 0.003 \mathrm{ab}$ & - & $0.018 \pm 0.001 \mathrm{a}$ & $0.048 \pm 0.009 \mathrm{de}$ \\
Sefora & $0.021 \pm 0.003 \mathrm{~cd}$ & $0.010 \pm 0.001 \mathrm{bc}$ & $0.012 \pm 0.003 \mathrm{a}$ & $0.010 \pm 0.002 \mathrm{a}$ \\
Skarb & $0.054 \pm 0.005 \mathrm{f}$ & $0.003 \pm 0.002 \mathrm{ab}$ & $0.046 \pm 0.007 \mathrm{a}$ & $0.165 \pm 0.007 \mathrm{f}$ \\
Spring Blush & $0.013 \pm 0.002 \mathrm{ab}$ & - & $0.047 \pm 0.004 \mathrm{~b}$ & $0.05 \pm 0.01 \mathrm{~cd}$ \\
Tsunami & $0.0155 \pm 0.0008 \mathrm{bc}$ & $0.021 \pm 0.003 \mathrm{~d}$ & $0.02 \pm 0.01 \mathrm{ab}$ & $0.021 \pm 0.002 \mathrm{abc}$ \\
Veselka & $0.009 \pm 0.004 \mathrm{ab}$ & - & $0.092 \pm 0.008 \mathrm{c}$ & $0.020 \pm 0.001 \mathrm{abc}$ \\
Velkopavlovická & $0.0045 \pm 0.0003 \mathrm{a}$ & & & $0.039 \pm 0.006 \mathrm{bcd}$ \\
\hline TN & & &
\end{tabular}

${ }^{\mathrm{z}}$ Not measured

The data are displayed as the mean \pm SD of three replications. Letters a- $\mathrm{f}$ refer to the grouping based on Tukey's honestly significant difference test.

Table 4. Titratable acidity, ascorbic acid, total phenolic content, flavonoids, antioxidant capacity, and carotenoids in fruits of apricot cultivars.

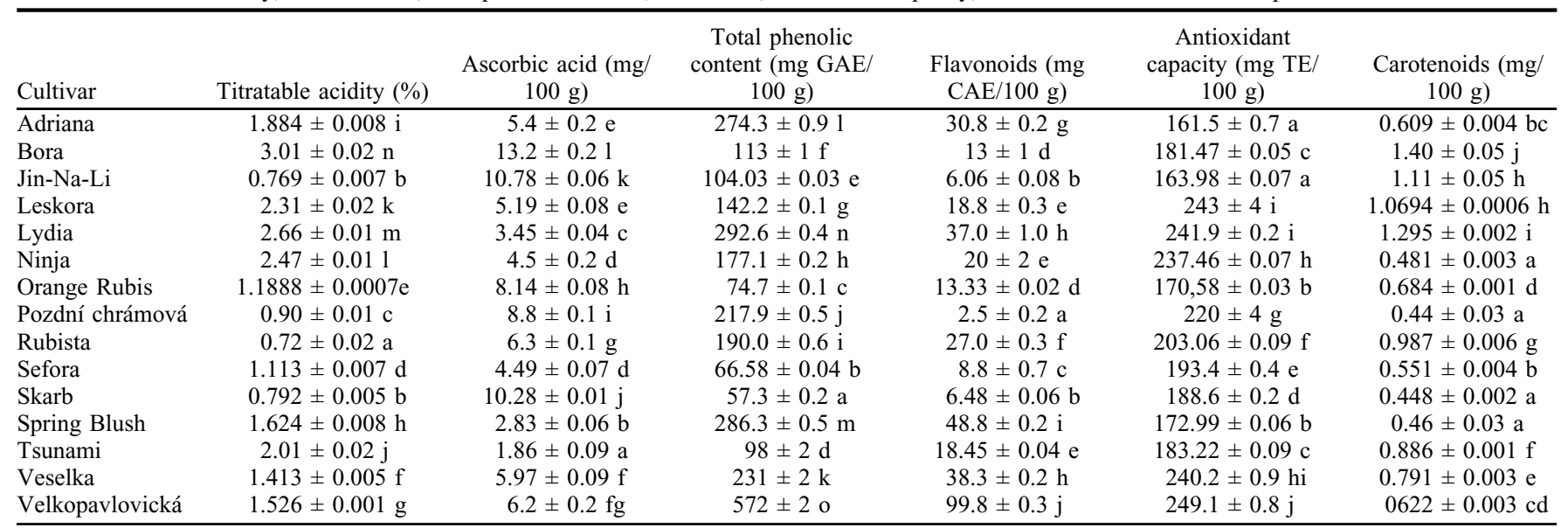

The data are displayed as the mean \pm SD of three replications. Letters a- $\mathrm{m}$ refer to the grouping based on Tukey's honestly significant difference test.

$\mathrm{GAE}=$ gallic acid equivalent; $\mathrm{CAE}=$ catechin equivalent; $\mathrm{TE}=$ Trolox equivalent.

99.78 mg CAE/100 g FW (Fig. 2, Table 4). Kafkaletou et al. (2019) reported that the total content of flavonoids was between 16.87 and $41.42 \mathrm{mg} \mathrm{CAE} / 100 \mathrm{~g} \mathrm{FW}$. Other studies of the total content of flavonoids in strawberries found it was as much as $70.5 \mathrm{mg} \mathrm{CAE} / 100 \mathrm{~g}$ FW (Meyers et al., 2003). Our results prove that apricots are a good source of flavonoids. Although the high contents of phenolics and flavonoids are an important parameter for fresh fruit, they can still have a negative effect on fruit processing. These compounds are a substrate for chemical and enzymatic reactions that lead to fruit browning during processing (Cheynier, 2012). Therefore, lowcontent cultivars can be a very good source for a wide range of apricot products.

Analyses of antioxidant components in products have quickly become a recognized profile primarily emphasizing antioxidant capacity as a quality index for many fruits 


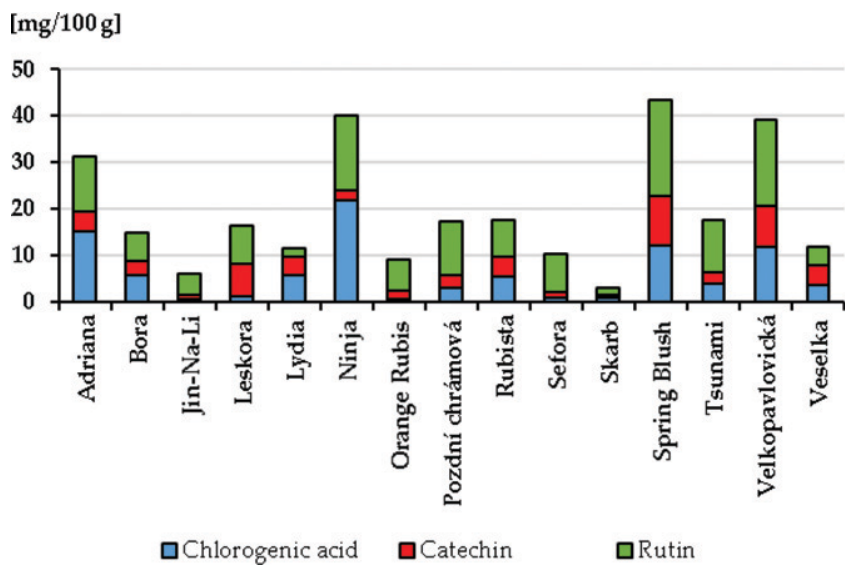

Fig. 1. Polyphenol compounds concentrations of chlorogenic acid, catechin, and rutin in fruits of apricot cultivars.

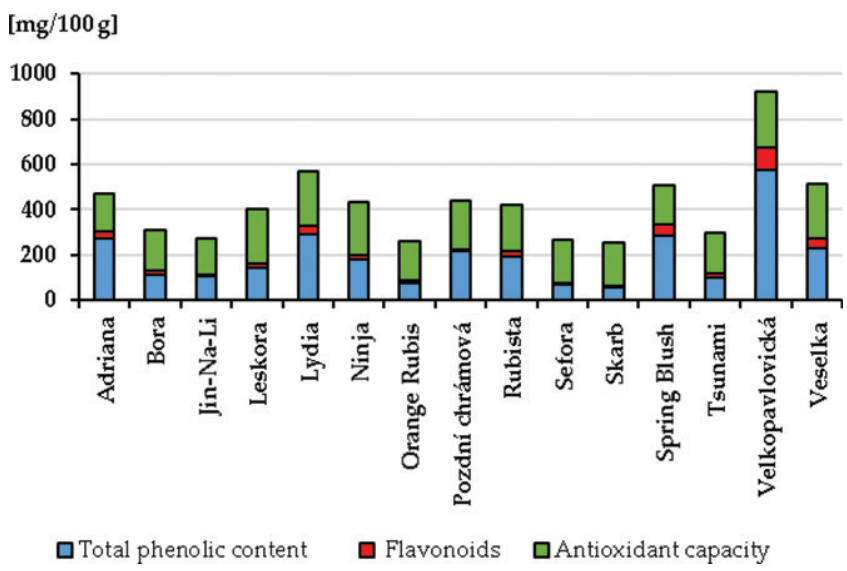

Fig. 2. Selected main substances that contribute to antioxidant capacity: total phenolic content, flavonoids, and antioxidant capacity.

Total antioxidant capacity $(\mathrm{mg} / 100 \mathrm{~g} \mathrm{FW})=123.85+0.49716^{*}$

Total phenolic content $(\mathrm{mg} / 100 \mathrm{~g}$ FW)

Correlation: $\mathrm{R}^{2}=0.80335$
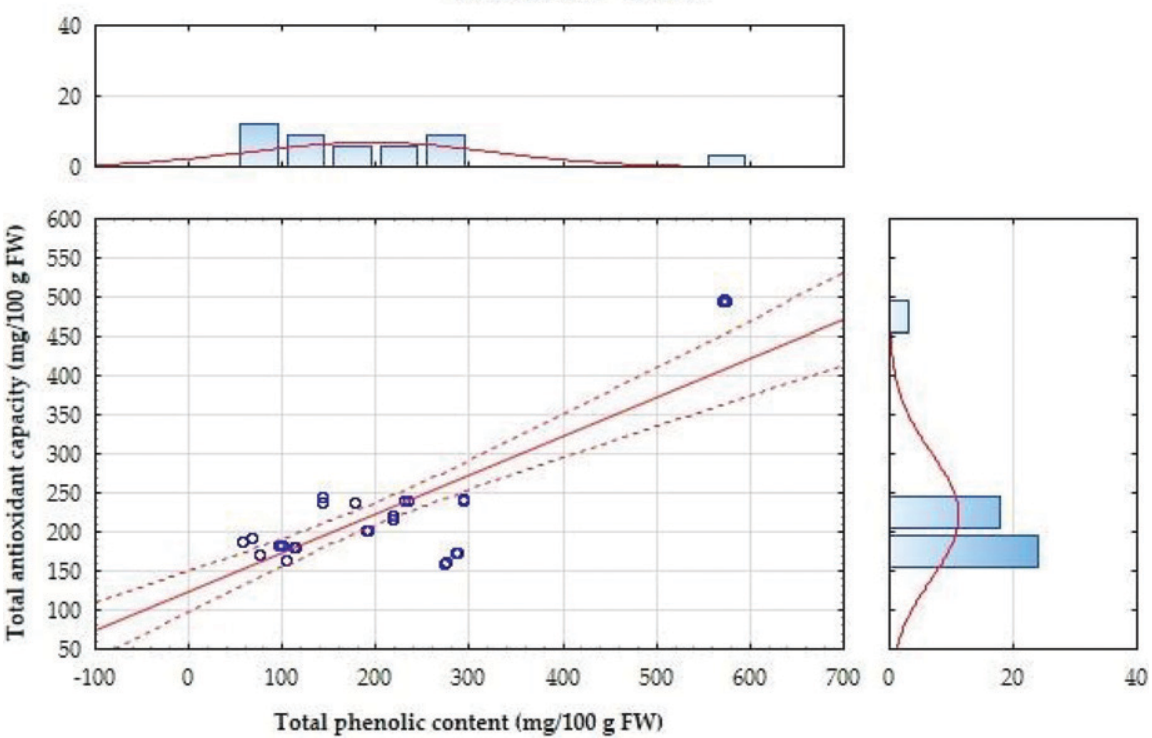

Fig. 3. Correlation between the total flavonoid content and total antioxidant capacity of apricot fruits. and vegetables. Antioxidant capacity determined by the DPPH method ranged from $161.47 \mathrm{mg} \mathrm{TE} / 100 \mathrm{~g} \mathrm{FW}$ to $249.08 \mathrm{mg} \mathrm{TE} /$ $100 \mathrm{~g} \mathrm{FW}$. A correlation between antioxidant capacity and total phenols has been previously described (Durmaz and Alpaslan, 2007; Vinson et al., 2001). In this study, a correlation $\left(R^{2}=0.8034\right)$ between antioxidant capacity and total phenolic content was found (Fig. 3), which supports the previous statement. Drogoudi et al. (2008) found a good correlation $\left(R^{2}=0.9542\right)$ in a set of 29 apricot cultivars, whereas other authors found a similar correlation $\left(R^{2}=0.9916\right)$ between antioxidant capacity and total phenolic content (Ali et al., 2011).

Only small amounts of carotenoids in the tested genotypes were measured. Many studies have indicated that apricots are a rich source of carotenoids, especially $\beta$-carotene, which accounts for $50 \%$ of the total carotenoids in this fruit (Radi et al., 2004). The total content in the tested cultivars ranged from 0.44 to $1.40 \mathrm{mg} / 100 \mathrm{~g}$ FW. Ruiz et al. (2005) reported that the measured carotenoid content ranged from 1.36 to $38.52 \mathrm{mg}$ of $\beta$-carotene equivalent/ $100 \mathrm{~g} \mathrm{FW}$ in Spanish cultivars. Akin et al. (2008) reported a total carotenoid content ranging from 14.83 to $91.89 \mathrm{mg}$ of $\beta$-carotene equivalent $/ 100 \mathrm{~g} \mathrm{FW}$. In other studies, the total carotenoid content in peaches was $12.0 \mu \mathrm{g} / \mathrm{g}$ FW (Campbell and PadillaZakour, 2013); however, in dates it ranged from 1.39 to $3.03 \mathrm{mg} / 100 \mathrm{~g} \mathrm{FW}$ (Al-Farsi et al., 2005).

Results of the content of ascorbic acid (vitamin C) in the tested cultivars ranged from 1.86 to $13.15 \mathrm{mg} / 100 \mathrm{~g} \mathrm{FW}$. These results are consistent with those of Thompson and Trenerry (1995). They measured an average value of $10 \mathrm{mg} / 100 \mathrm{~g} \mathrm{FW}$, which was similar to $6.38 \mathrm{mg} / 100 \mathrm{~g} \mathrm{FW}$ measured by Chauhan et al. (2001). Hegedüs et al. (2010) also studied vitamin $\mathrm{C}$, which ranged from 3.04 to $16.17 \mathrm{mg} / 100 \mathrm{~g} \mathrm{FW}$. Ali et al. (2011) reported a vitamin $\mathrm{C}$ content ranging between 67.39 and $90.94 \mathrm{mg} / 100 \mathrm{~g}$ of dry weight (DW), whereas Leong and Oey (2012) measured only $4 \mathrm{mg} / 100 \mathrm{~g} \mathrm{DW}$ in apricot fruits. In other studies that analyzed the vitamin $\mathrm{C}$ content in black mulberry and white mulberry genotypes, a content ranging between 10.123 and $18.220 \mathrm{mg} / 100 \mathrm{~g} \mathrm{FW}$ was measured (Eyduran et al., 2015). Our results indicate that apricots are a good source of vitamin C and emphasize the fact that the content of this vitamin is an important part of the overall assessment of fruit quality.

The acid content in the fruit is a key quality parameter and an important factor when determining the taste of the fruit. The titratable acid (TA) content indicates the concentration of organic acids present in the fruit. The total content of TAs found in our set of cultivars ranged from $0.77 \%$ to $3.01 \%$ malic acid in FW. These values are similar to those found in other publications. Hacõseferoğullarõ et al. (2007) measured TA contents ranging from $0.17 \%$ to $0.79 \%$ in $\mathrm{FW}$ of Turkish 
apricots. Similar values were also measured by Hagedüs et al. (2010), who reported that the contents ranged from $0.91 \%$ to $4.39 \%$. Gecer et al. (2020) reported TA contents between $1.09 \%$ and $1.89 \%$ in wild apricots. The TA values in this study are in accordance with those reported by other works (Milošević et al., 2010; Mratinić et al., 2011).

The findings of this study confirm the existence of phenolic compounds, organic acids, vitamin $\mathrm{C}$, flavonoids, antioxidant capacity, and carotenoids in apricot cultivars, which are important for healthy life and nutrition. Some cultivars are very interesting from a biochemical point of view and offer potential in breeding and further research. Velkopavlovická is a cultivar that has a very high content of several substances that were analyzed during our study. Therefore, it may be a suitable candidate in breeding programs to increase the contents of a number of substances (such as catechin or epicatechin) in fruit.

\section{Literature Cited}

Akbulut, M. and N. Artik. 2002. Phenolic compounds profile of apricot and wild apricot fruits and their changes during the process. In: Proceedings of 7th Food Congress in Turkey, Ankara, Turkey. 57-64.

Akin, E.B., I. Karabulut, and A. Topcu. 2008 Some compositional properties of main Malatya apricot (Prunus armeniaca L.) varieties. Food Chem. 107:939-948, https://doi.org/ 10.1016/j.foodchem.2007.08.052.

Al-Farsi, M., C. Alasalvar, A. Morris, M. Baron, and F. Shahidi. 2005. Comparison of antioxidant activity, anthocyanins, carotenoids, and phenolics of three native fresh and sun-dried date (Phoenix dactylifera $\mathrm{L}$.) varieties grown in Oman. J. Agr. Food Chem. 53:7592-7599, https://doi.org/10.1021/jf050579q.

Ali, S., T. Masud, and K.S. Abbasi. 2011. Physico-chemical characteristics of apricot (Prunus armeniaca L.) grown in northern areas of Pakistan. Scientia Hort. 130:386-392, https://doi. org/10.1016/j.scienta.2011.05.040.

Ali, S., T. Masud, K.S. Abbasi, T. Mahmood, and A. Hussai. 2015. Apricot: Nutritional potentials and health benefits-a review. Food Sci. Tech. 16:175-189. http://www.afst.valahia.ro/images/ documente/2015/issue1/full/section2/s02_w06_ full.pdf.

Campbell, O.E. and O.I. Padilla-Zakour. 2013 Phenolic and carotenoid composition of canned peaches (Prunus persica) and apricots (Prunus armeniaca) as affected by variety and peeling. Food Res. Int. 54:448-455, https://doi.org/ 10.1016/j.foodres.2013.07.016

Carbone, K., R. Ciccoritti, M. Paliotta, T. Rosato, M. Terlizzi, and G. Cipriani. 2018. Chemometric classification of early-ripening apricot (Prunus armeniaca $\mathrm{L}$.) germplasm based on quality traits, biochemical profiling, and in vitro biological activity. Scientia Hort. 227:187-195, https://doi.org/10.1016/j.scienta.2017.09.020

Chauhan, S.K., S.M. Tyagi, and D. Singh. 2001. Pectinolytic liquefaction of apricot, plum, and mango pulps for juice extraction. Int. J. Food Prop. 4:103-109, https://doi.org/10.1081/JFP100002190 .

Chen, F.X., X.H. Liu, and L.S. Chen. 2009. Developmental changes in pulp organic acid concentration and activities of acid-metabolising enzymes during the fruit development of two loquat (Eriobotrya japonica Lindl.) cultivars differing in fruit acidity. Food Chem. 114:657-664, https://doi.org/ 10.1016/j.foodchem.2008.10.003

Cheynier, V. 2012. Phenolic compounds: From plants to foods. Phytochem. Rev. 11:153-177, https://doi.org/10.1007/s11101-012-9242-8.

Dragovic-Uzelac, V., K. Delonga, B. Levaj, S. Djakovic, and J. Pospisil. 2005. Phenolic profiles of raw apricots, pumpkins, and their purees in the evaluation of apricot nectar and jam authenticity J. Agr. Food Chem. 53:4836-4842, https://doi. org/10.1021/jf040494+.

Dragovic-Uzelac, V., B. Levaj, V. Mrkic, D. Bursac, and M. Boras. 2007. The content of polyphenols and carotenoids in three apricot cultivars depending on stage of maturity and geographical region. Food Chem. 102:966-975, https://doi.org/10.1016/ j.foodchem.2006.04.001.

Drogoudi, P. D., S. Vemmos, G. Pantelidis, E Petri, C. Tzoutzoukou, I. Karayiannis. 2008. Physical characters and antioxidant, sugar, and mineral nutrient contents in fruit from 29 apricots (Prunus armeniaca L.) cultivars and hybrids. J. Agr. Food Chem. 56:10754-10760, https://doi.org/10.1021/jf801995x.

Dulf, F.V., D.C. Vodnar, E.H. Dulf, and A. Pintea. 2017. Phenolic compounds, flavonoids, lipids and antioxidant potential of apricot (Prunus armeniaca L.) pomace fermented by two filamentous fungal strains in solid state system. Chem. Cent. J. 11:92, https://doi.org/10.1186/ s13065-017-0323-z.

Durmaz, G. and M. Alpaslan. 2007. Antioxidant properties of roasted apricot (Prunus armeniaca L.) kernel. Food Chem. 100:1177-1181, https://doi.org/10.1016/j.foodchem.2005.10.067.

Enomoto, S., K. Yanaoka, H. Utsunomiya, T Niwa, K. Inada, H. Deguchi, K. Ueda, C. Mukoubayashi, I. Inoue, T. Maekita, K. Nakazawa, M. Iguchi, H. Tamai, M. Fujishiro, M. Oka, and M. Ichinose. 2010. Inhibitory effects of Japanese Apricot (Prunus mume Siebold et Zucc.; Ume) on Helicobacter pylori-related chronic gastritis. Eur. J. Clin. Nutr. 64:714, https://doi.org/10.1038/ejen.2010.70.

Eyduran, S.P., S. Ercisli, M. Akin, O. Beyhan, M.K. Geçer, E. Eyduran, and Y.E. Erturk. 2015. Organic acids, sugars, vitamin $C$, antioxidant capacity, and phenolic compounds in fruits of white (Morus alba L.) and black (Morus nigra L.) mulberry genotypes. J. Appl. Bot. Food Qual. 88:134-138, https://doi.org/ 10.5073/JABFQ.2015.088.019.

Fan, X., W. Jiao, X. Wang, J. Cao, and W. Jiang. 2018. Polyphenol composition and antioxidant capacity in pulp and peel of apricot fruits of various varieties and maturity stages at harvest Int. J. Food Sci. Technol. 53:327-336, https:// doi.org/10.1111/ijfs. 13589 .

Fatima, T., O. Bashir, G. Gani, T. Bhat, and N Jan. 2018. Nutritional and health benefits of apricots. Int. J. Unani Integr. Med. 2:05-09. https://www.unanijournal.com/articles/25/ 2-1-6217.pdf.

Fratianni, F., M.N. Ombra, A. D'Acierno, L. Cipriano, and F. Nazzaro. 2018. Apricots: Biochemistry and functional properties. Curr. Opin. Food Sci. 19:23-29, https://doi.org/ 10.1016/j.cofs.2017.12.006.

Gatti, E., G.B. Defilippi, S. Predieri, and R. Infante. 2009. Apricot (Prunus armeniaca L.) quality and breeding perspectives. J. Food Agr. Environ. 7:573-580.

Gecer, M.K., T. Kan, M. Gundogdu, S. Ercisli, G. Ilhan, and H.I. Sagbas. 2020. Physicochemical characteristics of wild and cultivated apricots (Prunus armeniaca L.) from Aras valley in Turkey. Genet. Resources Crop Evol. 67:935-945, https://doi.org/10.1007/s10722-020-00893-9.
Goliáš, J. and A. Němcová. 2009. Skladování a zpracování ovoce a zeleniny: (návody do cvičení). 1. vyd. Brno: Mendelova zemědělská a lesnická univerzita v Brně. ISBN 978-807375-331-3. (in Czech).

Göttingerová, M., M. Kumšta, and T. Nečas. 2020. Health-benefitting biologically active substances in edible apricot flowers. HortScience 55:1372-1377, https://doi.org/10.21273/ HORTSCI15038-20.

Hacõseferoğullarõ, H., I. Gezer, M. M. Özcan, B. MuratAsma. 2007. Postharvest chemical and physical-mechanical properties of some apricot varieties cultivated in Turkey. J. Food Eng. 79:364-373, https://doi.org/10.1016/j.jfoodeng. 2006.02.003

Hegedűs, A., R. Engel, L. Abrankó, E. Balogh, A. Blázovics, R. Hermán, J. Halász, S. Ercisli, A. Pedryc, and É. Stefanovits-Bányai. 2010. Antioxidant and antiradical capacities in apricot (Prunus armeniaca L.) fruits: Variations from genotypes, years, and analytical methods. J. Food Sci. 75:C722-C730, https://doi.org/ 10.1111/j.1750-3841.2010.01826.x.

Holm, G. 1954. Chlorophyll mutations in barley. Acta Agr. Scand. 4:457-471.

Kafkaletou, M., I. Kalantzis, A. Karantzi, M.V. Christopoulos, and E. Tsantili. 2019. Phytochemical characterization in traditional and modern apricot (Prunus armeniaca L.) cultivars-Nutritional value and its relation to origin. Scientia Hort. 253:195-202, https://doi.org/ 10.1016/j.scienta.2019.04.032.

Kalyoncu, I.H., M. Akbulut, and H. Coklar. 2009. Antioxidant capacity, total phenolics and some chemical properties of semi-mature apricot cultivars grown in Malatya, Turkey. World Appl. Sci. J. 6:519-523. http://www.idosi.org/wasj/ wasj6(4)/11.pdf

La Vecchia, C., A. Altieri, and A. Tavani. 2001. Vegetables, fruit, antioxidants, and cancer: A review of Italian studies. Eur. J. Nutr. 40:261-267, https://doi.org/10.1007/s394-0018354-9.

Leccese, A., S. Bartolini, and R. Viti. 2008. Total antioxidant capacity and phenolics content in fresh apricots. Acta Aliment. 37:65-76, https:// doi.org/10.1556/aalim.37.2008.1.6.

Leong, S.Y. and I. Oey. 2012. Effects of processing on anthocyanins, carotenoids and vitamin $\mathrm{C}$ in summer fruits and vegetables. Food Chem. 133:1577-1587, https://doi.org/10.1016/ j.foodchem.2012.02.052.

Long, H., Y.X. Zhu, M. Cregor, F.F. Tian, L. Coury, C.B. Kissinger, and P.T. Kissinger. 2001. Liquid chromatography coupled with multi-channel electrochemical detection for the determination of daidzin in rat blood sampled by an automated blood sampling system. J. Chromatogr. B Biomed. Sci. Appl. 772:173-177, https://doi.org/ 10.1016/S1570-0232(02)00087-9.

Meyers, K.J., C.B. Watkins, M.P. Pritts, and R.H. Liu. 2003. Antioxidant and antiproliferative activities of strawberries. J. Agr. Food Chem. 51:6887-6892, https://doi.org/ $10.1021 /$ jf034506n.

Milošević, T., N. Milošević, I. Glišić, and B. Krška. 2010. Characteristics of promising apricot (Prunus armeniaca L.) genetic resources in Central Serbia based on blossoming period and fruit quality. HortScience 37:46-55.

Mratinić, E., B. Popovski, T. Milošević, and M. Popovska. 2011. Evaluation of apricot fruit quality and correlations between physical and chemical attributes. Czech J. Food Sci. 29:161-170, https://doi.org/10.17221/67/2009 HORTSCI. 
Ou, B., D. Huang, M. Hapsch-Woodill, J.A. Flanagan, and E.K. Deemer. 2002. Analysis of antioxidant activities of common vegetables employing oxygen radical absorbance capacity (ORAC) and ferric reducing antioxidant power (FRAP) assays: A comparative study. J. Agr. Food Chem. 50:3122-3128, https://doi.org/ 10.1021/jf0116606.

Radi, M., M. Mahrouz, A. Jaouad, and M.J. Amiot. 2004. Characterization and identification of some phenolic compounds in apricot fruit (Prunus armeniaca L.). Sci. Aliments 24:173-184. https://sda.revuesonline.com/gratuit/sda24_2_ 173-184.pdf.

Rampáčková, E., M. Göttingerová, P. Gála, T. Kiss, S. Ercişli, and T. Nečas. 2021. Evaluation of protein and antioxidant content in apricot kernels as a sustainable additional source of nutrition. Sustainability 13:4742, https://doi. org/10.3390/su13094742.

Rapisarda, P., A. Tomaino, R. Cascio, F. Bonina, A. Pasquale, and A. Saija. 1999. Antioxidant effectiveness as influenced by phenolic content of fresh orange juices. J. Agr. Food Chem. 47:4718-4723, https://doi.org/10.1021/jf9901111.

Römer, S., P.D. Fraser, J.W. Kiano, C.A. Shipton, N. Misawa, W. Schuch, and P.M. Bramley.
2000. Elevation of the provitamin A content of transgenic tomato plants. Nat. Biotechnol. 18:666-669, https://doi.org/10.1038/76523.

Ruiz, D., J. Egea, M.I. Gil, and F.A. TomásBarberán. 2005. Characterization and quantitation of phenolic compounds in new apricot (Prunus armeniaca L.) varieties. J. Agr. Food Chem. 53:9544-9552, https://doi.org/ $10.1021 / \mathrm{jf051539p}$.

Sass-Kiss, A., J. Kiss, P. Milotay, M.M. Kerek, and M. Toth-Markus. 2005. Differences in anthocyanin and carotenoid content of fruits and vegetables. Food Res. Int. 38:1023-1029, https://doi.org/10.1016/j.foodres.2005.03.014.

Sawant, L., N. Pandita, and B. Prabhakar. 2010. Determination of gallic acid in Phyllanthus emblica Linn. dried fruit powder by HPTLC. J. Pharm. Bioallied Sci. 2:105-108, https://doi. org/10.4103/0975-7406.67012.

Scalzo, J., A. Politi, N. Pellegrini, B. Mezzetti, and M. Battino. 2005. Plant genotype affects total antioxidant capacity and phenolic contents in fruit. Nutrition 21:207-213, https://doi.org/ 10.1016/j.nut.2004.03.025.

Thompson, C.O. and V.C. Trenerry. 1995. A rapid method for the determination of total Lascorbic acid in fruits and vegetables by micellar electro- kinetic capillary chromatography. Food Chem. 53:43-50, https://doi.org/10.1016/0308-8146(95) 95784-4.

Turan, S., A. Topcu, I. Karabulut, H. Vural, and A.A. Hayaloglu. 2007. Fatty acid, triacylglycerol, phytosterol, and tocopherol variations in kernel oil of Malatya apricots from Turkey. J. Agr. Food Chem. 55:10787-10794, https://doi. org/10.1021/jf071801p.

Vinson, J.A., X. Su, L. Zubik, and P. Bose. 2001. Phenol antioxidant quantity and quality in foods. Fruits. J. Agric. Food Chem. 49:5315-5321, https://doi.org/10.1021/jf0009293.

Zbíral, J. 2005. Analýza rostlinného materiálu: Jednotné pracovní postupy; Vyd. 2, rozš. A přeprac; Ústřední Kontrolní a Zkušební Ústav Zemědělský: Brno, Czech Republic. (in Czech).

Zloch, Z., J. Čelakovský, and A. Aujezdská. 2004. Stanovení obsahu polyfenolì a celkové antioxidační kapacity $\mathrm{v}$ potravinách rostlinného původu. In Závěrečná zpráva o plnění výzkumného projektu podpořeného finančně Nadačním fondem Institutu Da-none; Ústav Hygieny Lékařské Fakulty UK Plzeň: Plzeň, Czech Republic. (In Czech). 